\title{
Wastewater infrastructure and the ecology and management of freshwater systems
}

\author{
Infraestrutura de saneamento e a ecologia e manejo de ecossistemas aquáticos \\ continentais
}

\author{
Krista Arminty Capps ${ }^{1,2 *}$ (1)
}

${ }^{1}$ Odum School of Ecology, University of Georgia - UGA, 140 East Green St., Athens, GA 30602, USA

${ }^{2}$ Savannah River Ecology Laboratory, University of Georgia - UGA, SRS Bldg 737A, Aiken, SC 29808, USA

*kcapps@uga.edu

Cite as: Capps, K.A. Wastewater infrastructure and the ecology and management of freshwater systems. Acta Limnologica Brasiliensia, 2019, vol. 31, e104

Abstract: Globally, freshwater resources are influenced by inputs of energy, nutrients, and pollutants from human wastewater. Local resource managers and policy-makers are tasked to address ecological and human-health concerns associated with aging and obsolete water infrastructure using limited financial resources. Nevertheless, there is limited information available describing how waste streams vary in their pollutant load or their subsequent effects on ecosystem structure and function in streams and rivers. Consequently, as wastewater systems degrade, local resource managers and policy makers are forced to develop watershed management strategies to deal with increasing effluent discharge without an understanding of how their decisions will influence local ecological processes or the structural and functional integrity of downstream habitats. Here, I discuss some of the ecological implications of obsolete or absent wastewater treatment, and describe how mismatches between the governance of wastewater management and watershed ecology may exacerbate environmental problems.

Keywords: infrastructure; freshwater ecology; wastewater; sewage; social-ecological-technical systems.

Resumo: Globalmente, os recursos de água doce são influenciados pelo aporte de energia, nutrientes e poluentes das águas residuais. Os gestores locais e os tomadores de decisão têm a tarefa de abordar as preocupaçóes ecológicas e de saúde humana associadas ao envelhecimento e à infraestrutura obsoleta de sistemas de tratamento de esgoto, utilizando recursos financeiros limitados. No entanto, há informaçôes limitadas disponíveis descrevendo como os ecossistemas aquáticos afetados variam em sua carga poluente ou seus efeitos subsequentes na estrutura e funçáo ecossistêmica. Consequentemente, à medida em que os sistemas de águas residuais se degradam, os gestores locais e os formuladores de políticas são forçados a desenvolver estratégias de gestão de bacias hidrográficas para lidar com o aumento da descarga de efluentes sem entender como suas decisóes influenciarão os processos ecológicos locais ou a integridade estrutural e funcional dos habitats a jusante. Neste artigo, eu discuto algumas das implicaçóes ecológicas do tratamento de águas residuais obsoletas ou ausentes, e descrevo como os desequilíbrios entre a gestão de águas residuais e a ecologia das bacias hidrográficas podem exacerbar os problemas ambientais.

Palavras-chave: infraestrutura; ecologia de água doce; águas residuais; esgoto; sistemas sócio-ecológico-técnicos. 
Aging and obsolete water infrastructure is a critical problem threatening economic stability, human welfare, and the environment throughout the world (Liu et al., 2013; Rahm et al., 2013). The volume of wastewater produced globally is substantial. For example, estimates suggest that the amount of wastewater generated by manufacturing activities and domestic use in 2010 was approximately $450 \mathrm{~km}^{3}$ (Flörke et al., 2013), a volume greater than the entire volume of water in Lake Erie $\left(-430 \mathrm{~km}^{3}\right)$, one of the Great Lakes of North America. Unfortunately, we have a limited understanding of how waste streams vary in their pollutant load and how they may differentially affect ecosystem structure and function in freshwater systems (Singer \& Battin, 2007).

In many regions of the world, rivers and streams receive wastewater discharge that is delivered both intentionally and inadvertently. The quantity and quality of these waste streams are heterogeneousthey are influenced by human population density, the type and volume of waste produced, and the quality of and access to wastewater treatment (Rahm et al., 2013; Cease et al., 2015; Capps et al., 2016). However, even in wealthier economies, few jurisdictions reliably maintain records documenting the composition and volume of effluent entering surface and ground water supplies. Though data are relatively limited, estimates suggest over $80 \%$ of global wastewater is discharged without any treatment, degrading water quality, and endangering human health and the environment (UN WATER, 2017). Patterns in treatment capabilities are strongly linked with development status. In higher-income economies, approximately $70 \%$ of municipal and industrial wastewater is treated before discharge. In middle income economies, this value declines to $28-38 \%$, and in lower-income economies, the value plummets to just $8 \%$ (UN WATER, 2017).

Here, I briefly outline some of the ecological implications of failing or absent wastewater treatment and highlight some of the important gaps in our knowledge about wastewater inputs that may compromise how we understand river ecology. I also describe how mismatches between policy and governance of wastewater treatment and watershed ecology may exacerbate environmental problems, and compromise the provisioning of freshwater ecosystem services. Lastly, I briefly describe ideas emerging from the study of urban systems that may provide new insight in supporting freshwater scientists in designing policy-relevant, ecologically-centered research questions to address the ecological impacts of aging and obsolete wastewater systems.

\section{Ecological Implications of Wastewater Inputs in Freshwater Systems}

Wastewater inputs into lotic systems have the potential to either stimulate or suppress ecosystem processes, and affect the quality and quantity of services provided by freshwater systems (Morrissey et al., 2013). Untreated wastewater is a mixture of inorganic solutes (e.g, soluble reactive phosphorus, nitrate, and ammonium), organic solutes (e.g, dissolved organic matter), particulate organic matter (e.g., feces/bacteria), and pharmaceuticals and personal care products (PPCPs) that can affect biogeochemical cycling and riverine food webs through both algal and detrital pathways. Ecosystem processes, such as primary productivity and the decomposition of organic matter, are frequently limited by the availability of nitrogen, phosphorus, or a combination of both elements (Archer et al., 2015). Hence, wastewater effluent may stimulate ecosystem processes by functioning as a "spatial subsidy" (Polis et al., 1997), supplying terrestrially-derived energy and elements to aquatic systems (Singer \& Battin, 2007), and generating spatial and temporal variability in the function of riverine systems (Gucker et al., 2006). However, limited work has been conducted to examine wastewater from a subsidy perspective to consider how sewage-derived energy and nutrients may alter the structure and function of running waters at larger spatial scales (Walsh et al., 2005; Singer \& Battin, 2007).

Exposure to PPCPs from wastewater effluent is a pressing concern for natural resource managers and freshwater scientists (Rosi-Marshall \& Royer, 2012; Bernhardt et al., 2017). Work examining PPCPs has demonstrated they are pervasive in wastewater (Brausch \& Rand, 2011; Corcoll et al., 2015), and have the potential to affect aquatic communities and alter ecosystem processes (Rosi et al., 2018). Local authorities are particularly concerned about the potential environmental and human-health consequences of PPCPs, as they often persist through conventional drinking water treatment (Wang \& Wang, 2016) and have the potential to negatively affect human populations. As federal regulations are developed to reduce or remove PPCPs from wastewater effluent, local governments may be technically and financially challenged to meet new environmental standards (Yang et al., 2017). Hence, additional research elucidating the 
effects of wastewater-derived PPCPs on freshwater systems is a pressing need to inform effective wastewater treatment decisions and to prioritize management actions.

Though the addition of human waste to fresh waters is commonplace (Segura et al., 2015; Capps et al., 2016), limited work has been devoted to understanding the influence of wastewater inputs on spatial and temporal variation of ecosystem processes in river networks. The composition of wastewater effluent and its impacts on riverine structure and function are most likely heterogeneous. Variation in the volume and contents of wastewater streams entering the environment is strongly influenced by the surrounding human population (e.g., total population, population density, human diets, type of and rate of development, etc.) and by wastewater treatment infrastructure (e.g., centralized vs. decentralized, age, condition, capacity, etc.) (Cease et al., 2015). For example, in an aging, centralized waste treatment system (i.e., sewer system), increasing discharge may decrease the local effects of an unintentional, relatively constant source of pollution entering a watershed (e.g, leaky sewer pipe), but may simultaneously increase the spatial extent of a given effect downstream (Figure 1A). Conversely, certain sources of wastewater discharge (e.g., combined sewer overflow) are intentionally designed, but they are only present during high flows, and can have large, but infrequent effects downstream (Figure 1B).

Wastewater effluent may also interact with physicochemical factors, such as discharge or nutrient limitation status, and produce spatial and temporal variability in the extent of changes in ecosystem structure and function in receiving waters (Clark et al., 2006; Askey et al., 2007; Aristi et al., 2015). Water chemistry samples collected from wastewater effluent and from the water column from sites in a large drainage in southern Mexico illustrate how differences in ambient nutrient concentrations may mediate the impact of waste effluent in a system (Figure 2). In streams in the Usumacinta Watershed, ambient water chemistry is often characterized by concentrations of soluble reactive phosphorus (SRP) that are below the level of detection $\left(-2 \mu \mathrm{g} \mathrm{L}^{-1}\right)$, and growth of primary producers in streams in the Usumacinta is often limited by access to phosphorus (e.g., Capps \& Flecker, 2013) (Figure 2). Conversely, streams in the Grijalva are often characterized by greater concentrations of SRP in the water column. Effluent in both basins is rich in phosphorus, suggesting that from a nutrient perspective, wastewater inputs may have a much larger impact on ecosystem function in streams in the Usumacinta, especially in the dry season when nutrients supplied by runoff is limited and when in-stream flows are low (Figure 2). Understanding how physicochemical factors interact with built infrastructure to mediate the effects of wastewater discharge on freshwater systems is essential to effectively manage the quality and quantity of freshwater resources.

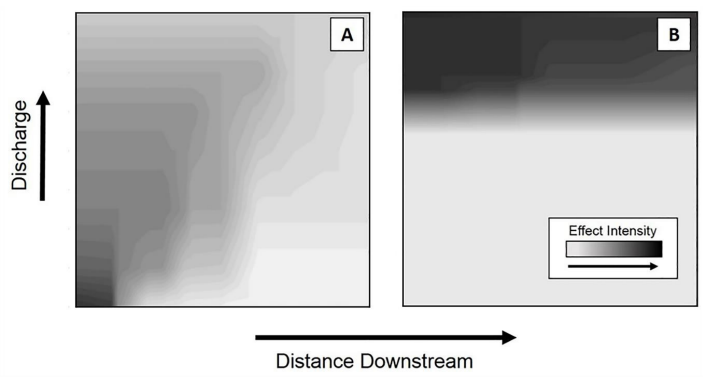

Figure 1. Theoretical spatial relationships between discharge and the potential impact of waste streams on ecosystem structure and function and the provisioning of ecosystem services. (A) The effect of a relatively constant, localized source of pollution entering a watershed (e.g, unintentional leak in sewer system) may experience decreases in the localized effect, but increases the spatial extent of the effect downstream at high flows; (B) Conversely, other sources of wastewater pollution (e.g., intentionally-designed combined sewer overflow) are only present during high flows and can have large, but infrequent effects locally and downstream.

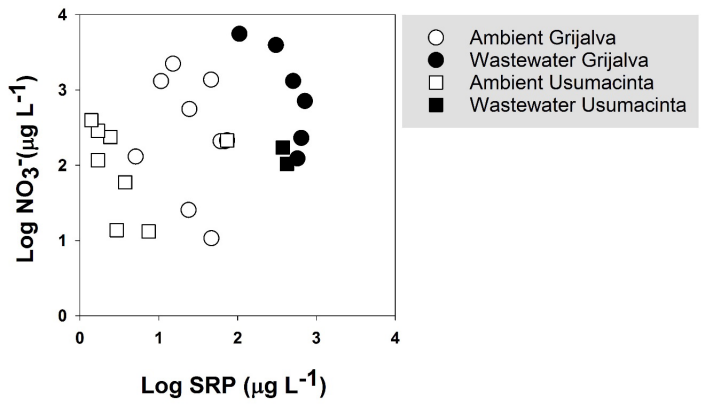

Figure 2. Relationship between nitrate $\left(\mathrm{NO}_{3}^{-}\right)$and soluble reactive phosphorus (SRP) concentrations from the water column (ambient; white) and in wastewater discharge (wastewater; black) entering the Grijalva (O) and Usumacinta ( $\square$ ) basins. SRP concentrations in subsidies are greater than ambient water SRP, and the SRP concentrations are much less variable than the nitrate concentrations in wastewater. Samples were collected (Lamberti \& Hauer, 2017) and analyzed (Rice et al., 2017) using standard methods. 
However, the number of jurisdictions that collect and maintain data pertaining to location and condition of wastewater infrastructure and the quality and quantity of effluent entering surface and groundwater is extremely limited, especially in poorer economies (UN WATER, 2017). Consequently, as human populations grow and wastewater systems degrade, local resource managers and policy makers are forced to develop watershed management strategies to deal with increasing volumes of wastewater with limited data to support how their decisions will influence local ecological processes or the integrity of downstream habitats (Rahm et al., 2013).

\section{Challenges to Effective Wastewater Management}

Wastewater-management decisions must balance a broad range of goals including public health, economic development, and environmental protection (Huang et al., 2014). Governance of wastewater systems is often a shared responsibility among local, regional, and federal governments. For example, wastewater management in the United States of America (US) divides responsibility for environmental protection between federal and state authorities (Dunn \& Boian, 2013). In the US, state and federal statutes, regulations, and financing programs influence how wastewater services are provided; however, local governments make most of the decisions about the installation and maintenance of wastewater treatment infrastructure (Craig, 2010). Similar systems of multi-tiered governance and financing of wastewater management are found throughout the world (UN WATER, 2017). Frequently, environmental regulations at the local level are influenced by financial resources, political culture, the nature of the environmental problems, and the amount of social capital present in the community (Schultz et al., 2015). Local government officials make decisions in complex legal, social, political, economic, and ecological settings. Yet, local decision-makers have relatively little access to the technical expertise and ecological data needed to make effective environmental decisions. This is especially true in developing economies, where the majority of financing and technical support for the development of wastewater infrastructure and implementation of environmental monitoring comes from international aid (UN WATER, 2017).

The social, political, and economic complexities surrounding the development and implementation of effective wastewater treatment are immense; thus, financing improvements in wastewater infrastructure is a challenge everywhere. Typically, a large portion of water infrastructure is underground and out of sight; hence, elected officials interested in investing resources in prominent environmental problems may be reluctant to support water infrastructure improvements (Cao \& Prakash, 2012). Large-scale wastewater management is very expensive, and the benefits derived from investment in improved treatment are often enjoyed by downstream communities and/or future generations, rather than by those investing resources to reduce pollution. Improved water treatment is only achieved when all or the great majority of the public, follow the rules (Hophmayer-Tokich, 2006; UN WATER, 2017). In large river networks, this means that effective wastewater management at the basin level frequently requires consistent, multinational cooperation. In richer countries, the agencies tasked to address water quality issues resulting from failing wastewater infrastructure describe the problem as a "gathering storm", which will inevitably require significant financial investment to avoid human health risks and continued environmental degradation (EPA, 2002). In lower-income economies, untreated waste contaminates drinking water supplies, exposes human populations to waterborne illnesses, and compromises subsistence livelihoods that depend on freshwater ecosystems (Massoud et al., 2009; Brands, 2014; UN WATER, 2017). Globally, wastewater management and governance at the local level may have large ecological and socioeconomic impacts downstream. In order to inform effective management actions at the local-level, there is a ubiquitous need for scientists and natural resource managers to collaborate in constructing and maintaining basin-wide databases characterizing wastewater infrastructure and the quality and quantity of effluent entering the environment (Eakin et al. 2017; UN WATER, 2017).

\section{Integrating the Social, Ecological and Technical Components of River Systems}

The conservation of resources throughout the world is challenged by mismatches in spatial and temporal variability among ecological processes, management decisions, and the construction and maintenance of infrastructure (Baron et al., 2002). This can be especially true in freshwater ecosystems (Poff et al., 2010). For instance, in managing the quality and quantity of water for both human populations and the natural environment-a global challenge-there are inherent complications in predicting how the synergistic effects of water withdrawals and the 
input of wastewater will vary through space and time. Yet, neither federal policies aimed at water quality protection, nor the local design, operation, or maintenance of water treatment infrastructure reflect the inherent variability in interactions between the natural and built systems. Biophysical researchers have recognized the need for future design and management of infrastructure to protect the dynamic character of ecosystems (Poff et al., 2010). Yet, integrating the concept of spatially and temporally dynamic systems into the design of resource management policies or water-related infrastructure is still uncommon.

There is a great need to study freshwater ecology and examine wastewater management decisions through a lens that integrates the social, ecological, and technical characteristics of systems (SETS). Applying a SETS framework could enhance our understanding of how freshwater ecosystem structure and function change in response to management decisions (e.g., investing in wastewater infrastructure) and governance (e.g., enforcing environmental regulations), and illuminate how management decisions and governance can be influenced by having a greater understanding of environmental conditions. The SETS framework, first described by Grimm et al. (2015) as a way to use an ecosystem approach to study cities, could be effectively applied to studying the influence of urban and rural wastewater systems on rivers and streams. The approach underscores the importance of infrastructure in mediating relationships between human activities and ecosystems processes, emphasizing the point that decisions about infrastructure can exacerbate or mediate human impacts on the environment (McPhearson et al., 2016). Though intentionally designed for urban systems with higher human population densities, the SETS framework could be an effective way to consider how water infrastructure mediates freshwater ecosystem dynamics in watersheds throughout the globe. In oligotrophic systems, even small inputs of nitrogen or phosphorus from effluent should have the potential to influence ecosystem-level processes. Similarly, even in remotely populated and developed areas, chemical or thermal pollution from industrial activities can have large impacts on aquatic communities.

Society relies on streams and rivers to perform valuable ecosystem services, yet human development in watersheds alters the structure and function of flowing waters. As wastewater systems continue to degrade, local resource managers are forced to develop watershed management strategies to deal with increasing effluent discharge (Rahm et al., 2013) without an understanding of how their decisions will influence local ecological processes or the structural and functional integrity of downstream habitats. Our ability to manage streams to maintain services and to minimize ecosystem alteration is inhibited by a lack of understanding of the mechanisms of degradation, and by the global variability in human development and the physicochemical and biological characteristics of ecosystems. Globally, local resource managers and policy-makers are tasked to address environmental and human-health concerns associated with aging and obsolete water infrastructure using limited financial resources (Panebianco \& Pahl-Wostl, 2006; GAO, 2013; Rahm et al., 2013). Therefore, they must adopt systems to prioritize management actions to address issues that present the greatest threat to human health and the environment. Research is needed to populate models that can predict spatial and temporal variability in the relationships between wastewater management and governance, and the integrity of freshwater ecosystems throughout the globe. Embracing the need to study wastewater inputs as both a pollutant and a subsidy, and employing new frameworks, such as SETS, that integrate built infrastructure and environmental governance into our understanding of how freshwater systems work and into our predictions of how they will continue to change, are critical steps to advance our understanding of freshwater ecosystem ecology.

\section{Acknowledgements}

I would like to thank the reviewers who provided valuable feedback on earlier versions of the manuscript.

\section{References}

ARCHER, S.K., ALLGEIER, J.E., SEMMENS, B.X. HEPPELL, S.A., PATTENGILL-SEMMENS, C.V., ROSEMOND, A.D., BUSH, P.G., MCCOY, C.M., JOHNSON, B.C. and LAYMAN, C.A. Hot moments in spawning aggregations: implications for ecosystemscale nutrient cycling. Coral Reefs, 2015, 34(1), 19-23. http://dx.doi.org/10.1007/s00338-014-1208-4.

ARISTI, I., VON SCHILLER, D., ARROITA, M., BARCELO, D., PONSATI, L., GARCIA-GALAN, M.J., SABATER, S., ELOSEGI, A. and ACUNA, V. Mixed effects of effluents from a wastewater treatment plant on river ecosystem metabolism: subsidy or stress? Freshwater Biology, 2015, 60(7), 1398-1410. http:// dx.doi.org/10.1111/fwb.12576. 
ASKEY, P.J., HOGBERG, L.K., POST, J.R., JACKSON, L.J., RHODES, T. and THOMPSON, M.S. Spatial patterns in fish biomass and relative trophic level abundance in a wastewater enriched river. Ecology Freshwater Fish, 2007, 16(3), 343-353. http://dx.doi. org/10.1111/j.1600-0633.2007.00221.x.

BARON, J.S., POFF, N.L., ANGERMEIER, P.L., DAHM, C.N., GLEICK, P.H., HAIRSTON JUNIOR, N.G., JACKSON, R.B., JOHNSTON, C.A., RICHTER, B.D. and STEINMAN, A.D. Meeting the ecological and societal needs for freshwater. Ecological Applications, 2002, 12(5), 1247-1260. http:// dx.doi.org/10.1890/1051-0761(2002)012[1247:MEA SNF]2.0.CO;2.

BERNHARDT, E.S., ROSI, E.J. and GESSNER, M.O. Synthetic chemicals as agents of global change. Frontiers in Ecology and the Environment, 2017, 15(2), 84-90. http://dx.doi.org/10.1002/fee.1450.

BRANDS, E. Prospects and challenges for sustainable sanitation in developed nations: a critical review. Environmental Reviews, 2014, 22(4), 346-363. http:// dx.doi.org/10.1139/er-2013-0082.

BRAUSCH, J.M. and RAND, G.M. A review of personal care products in the aquatic environment: environmental concentrations and toxicity. Chemosphere, 2011, 82(11), 1518-1532. http://dx.doi.org/10.1016/j. chemosphere.2010.11.018. PMid:21185057.

CAO, X. and PRAKASH, A. Trade competition and environmental regulations: domestic political constraints and issue visibility. The Journal of Politics, 2012, 74(1), 66-82. http://dx.doi.org/10.1017/ S0022381611001228.

CAPPS, K.A. and FLECKER, A.S. 2013. Invasive aquarium fish transform ecosystem nutrient dynamics. Proceedings of the Royal Society B. 280, 1-7. http://dx.doi. org/10.1098/rspb.2013.1520.

CAPPS, K.A., BENTSEN, C.N. and RAMIREZ, A. Poverty, urbanization, and environmental degradation: urban streams in the developing world. Freshwater Science, 2016, 35(1), 429-435. http://dx.doi. org/10.1086/684945.

CEASE, A.J., CAPPS, K.A., GATES, K.K., MCCRACKIN, M.L. and NIDZGORSKI, D.A. Consumer-driven nutrient dynamics in urban environments: the stoichiometry of human diets and waste management. Oikos, 2015, 124(7), 931-948. http://dx.doi. org/10.1111/oik.02391.

CLARK, S.E., BURIAN, S., PITT, R. and FIELD, R. Urban wet-weather flows. Water Environment Research, 2006, 78(10), 1133-1192. http://dx.doi. org/10.2175/106143006X119378.

CORCOlL, N., CASEllas, M., HUERTA, B., GUASCH, H., ACUNA, V., RODRIGUEZMOZAZ, S., SERRA-COMPTE, A., BARCELO, D. and SABATER, S. Effects of flow intermittency and pharmaceutical exposure on the structure and metabolism of stream biofilms. The Science of the Total
Environment, 2015, 503, 159-170. http://dx.doi. org/10.1016/j.scitotenv.2014.06.093. PMid:25017633.

CRAIG, R.K. Adapting water federalism to climate change impacts: energy policy, food security, and the allocation of water resources. Environmental \& Energy Law \& Policy Journal, 2010, 183, 5-22.

DUNN, A.D. and BOIAN, M. Postcards from the Edge: perspectives to Reinvigorate Clean Water Act Cooperative Federalism. George Washington Journal of Energy and Environmental Law, 2013, 68, 122-134.

EAKIN, H., BOJÓRQUEZ-TAPIA, L.A., JANSSEN, M.A., GEORGESCU,M., MANUEL-NAVARRETE, D., VIVONI, E.R., ESCALANTE, A.E. and BAEZA-CASTRO, A., MAZARI-HIRIART, M. and LERNER, A. M. Opinion: urban resilience efforts must consider social and political forces. Proceedings of the National Academy of Sciences, 2017, 114(2), 186-189. http://dx.doi.org/10.1073/pnas.1620081114.

ENVIRONMENTAL PROTECTION AGENCY - EPA The clean water and drinking water infrastructure gap analysis. Washington: United States Environmental Protection Agency, 2002.

FLÖRKE, M., KYNAST, E., BÄRLUND, I., EISNER, S., WIMMER, F. and ALCAMO, J. Domestic and industrial water uses of the past 60 years as a mirror of socio-economic development: a global simulation study. Global Environmental Change, 2013, 23(1), 144-156. http://dx.doi.org/10.1016/j.gloenvcha.2012.10.018.

GOVERNMENT ACCOUNTABILITY OFFICE $\mathrm{GAO}$. Approaches and issues for financing drinking water and wastewater infrastructure. Washington: Government Accountability Office, 2013.

GRIMM, N.B., COOK, E.M., HALE, R.L. and IWANIEC, D.M. A broader framing of ecosystem services in cities. In K. C. SETO, W. D. SOLECKI, and C. A. GRIFFITH, editors. The routledge handbook of urbanization and global environmental change. Abingdon: Routledge and CRC Press, 2015.

GUCKER, B., BRAUNS, M. and PUSCH, M.T. Effects of wastewater treatment plant discharge on ecosystem structure and function of lowland streams. Journal of the North American Benthological Society, 2006, 25(2), 313-329. http://dx.doi.org/10.1899/08873593(2006)25[313:EOWTPD]2.0.CO;2.

HOPHMAYER-TOKICH, S. Wastewater Management Strategy: centralized $v$. decentralized technologies for small communities. Leeuwarden, The Netherlands: The Center for Clean Technology and Environmental Policy, University of Twente, at the Cartesius Institute, 2006.

HUANG, W., WELCH, E. and CORLEY, E. Public sector voluntary initiatives: the adoption of the environmental management system by public waste water treatment facilities in the United States. Journal of Environmental Planning and Management, 2014, 57(10), 1531-1551. http://dx.doi.org/10.1080/09640568.2013.816630. 
LAMBERTI, G. and HAUER, F.R. Methods in stream ecology. USA: Academic Press, 2017. vol. 2: Ecosystem Function.

LIU, S., CROSSMAN, N.D., NOLAN, M. and GHIRMAY, H. Bringing ecosystem services into integrated water resources management. Journal of Environmental Management, 2013, 129, 92-102. http://dx.doi.org/10.1016/j.jenvman.2013.06.047. PMid:23900082.

MASSOUD, M. A., TARHINI, A. and NASR, J. A. Decentralized approaches to wastewater treatment and management: applicability in developing countries. Journal of Environmental Management, 2009, 90(1), 652-659. http://dx.doi.org/10.1016/j. jenvman.2008.07.001. PMID: 18701206.

MCPHEARSON, T., HAASE, D., KABISCH, N. and GREN, A. Advancing understanding of the complex nature of urban systems. Ecological Indicators, 2016, 70, 566-573. http://dx.doi.org/10.1016/j. ecolind.2016.03.054.

MORRISSEY, C.A., BOLDT, A., MAPSTONE, A., NEWTON, J. and ORMEROD, S.J. Stable isotopes as indicators of wastewater effects on the macroinvertebrates of urban rivers. Hydrobiologia, 2013, 700(1), 231-244. http://dx.doi.org/10.1007/ s10750-012-1233-7.

PANEBIANCO, S. and PAHL-WOSTL, C. Modelling socio-technical transformations in wastewater treatment: a methodological proposal. Technovation, 2006, 26(9), 1090-1100. http://dx.doi.org/10.1016/j. technovation.2005.09.017.

POFF, N.L., RICHTER, B.D., ARTHINGTON, A.H., BUNN, S.E., NAIMAN, R.J., KENDY, E., ACREMAN, M., APSE, C., BLEDSOE, B.P., FREEMAN, M.C., HENRIKSEN, J., JACOBSON, R.B., KENNEN, J.G., MERRITT, D.M., O'KEEFFE, J.H., OLDEN, J.D., ROGERS, K., THARME, R.E. and WARNER, A. The Ecological Limits of Hydrologic Alteration (ELOHA): a new framework for developing regional environmental flow standards. Freshwater Biology, 2010, 55(1), 147-170. http://dx.doi. org/10.1111/j.1365-2427.2009.02204.x.

POLIS, G.A., ANDERSON, W.B. and HOLT, R.D. Toward an integration of landscape and food web ecology: the dynamics of spatially subsidized food webs. Annual Review of Ecology and Systematics, 1997, 28(1), 289-316. http://dx.doi.org/10.1146/annurev. ecolsys.28.1.289.

RAHM, B.G., VEDACHALAM, S., SHEN, J., WOODBURY, P.B. and RIHA, S.J. A watershedscale goals approach to assessing and funding wastewater infrastructure. Journal of Environmental Management, 2013, 129, 124-133. http://dx.doi.org/10.1016/j. jenvman.2013.06.053. PMid:23911765.

RICE, E., BAIRD, R. and EATON, A., editors. Standard methods for the examination of water and wastewater. 23th ed. Washington: American Public Health
Association, American Water Works Association, Water Environment Federation, 2017.

ROSI, E.J., BECHTOLD, H.A., SNOW, D., ROJAS, M., REISINGER, A.J. and KELLY, J.J. Urban stream microbial communities show resistance to pharmaceutical exposure. Ecosphere, 2018, 9(1), 16. http://dx.doi.org/10.1002/ecs2.2041.

ROSI-MARSHALL, E.J. and ROYER, T.V. Pharmaceutical compounds and ecosystem function: an emerging research challenge for aquatic ecologists. Ecosystems (New York, N.Y.), 2012, 15(6), 867-880. http://dx.doi. org/10.1007/s10021-012-9553-z.

SCHULTZ, L., FOLKE, C., ÖSTERBLOM, H. and OLSSON, P. Adaptive governance, ecosystem management, and natural capital. Proceedings of the National Academy of Sciences of the United States of America, 2015, 112(24), 7369-7374. http://dx.doi. org/10.1073/pnas.1406493112. PMid:26082542.

SEGURA, P.A., TAKADA, H., CORREA, J.A., EL SAADI, K., KOIKE, T., ONWONA-AGYEMAN, S., OFOSU-ANIM, J., SABI, E.B., WASONGA, O.V., MGHALU, J.M., SANTOS JUNIOR, A.M., NEWMAN, B., WEERTS, S. and YARGEAU, V. Global occurrence of anti-infectives in contaminated surface waters: impact of income inequality between countries. Environment International, 2015, 80, 8997. http://dx.doi.org/10.1016/j.envint.2015.04.001. PMid:25910860.

SINGER, G.A. and BATTIN, T.J. Anthropogenic subsidies alter stream consumer-resource stoichiometry, biodiversity, and food chains. Ecological Applications, 2007, 17(2), 376-389. http://dx.doi.org/10.1890/060229. PMid:17489246.

UN WATER. The United Nations World Water Development Report 2017: wastewater the untapped resource. Paris: UNESCO, 2017.

WALSH, C.J., ROY, A.H., FEMINELLA, J.W., COTTINGHAM, P.D., GROFFMAN, P.M. and MORGAN II , R.P. The urban stream syndrome: current knowledge and the search for a cure. Journal of the North American Benthological Society, 2005, 24(3), 706-723. http://dx.doi.org/10.1899/04-028.1.

WANG, J. and WANG, S. Removal of pharmaceuticals and personal care products (PPCPs) from wastewater: a review. Journal of Environmental Management, 2016, 182, 620-640. http://dx.doi.org/10.1016/j. jenvman.2016.07.049. PMid:27552641.

YANG, Y., OK, Y.S., KIM, K.-H., KWON, E.E. and TSANG, Y.F. Occurrences and removal of pharmaceuticals and personal care products (PPCPs) in drinking water and water/sewage treatment plants: a review. The Science of the Total Environment, 2017, 596-597, 303-320. http://dx.doi.org/10.1016/j. scitotenv.2017.04.102. PMid:28437649.

Received: 05 March 2019 Accepted: 09 May 2019 